\title{
Planning a Green Infrastructure Network from Theory to Practice: The Case Study of Setúbal, Portugal
}

\author{
José C. Ferreira $^{1, * \mathbb{D}}$, Renato Monteiro ${ }^{1, *(\mathbb{D})}$ and Vasco R. Silva ${ }^{2}$ \\ 1 MARE-Marine and Environmental Sciences Centre, Department of Environmental Sciences and \\ Engineering, NOVA School of Science and Technology, Campus de Caparica, NOVA University Lisbon, \\ 2829-516 Caparica, Portugal \\ 2 Urban Planning Division of Setúbal City Council, Edifício dos Ciprestes, Avenida dos Ciprestes $\mathrm{N}^{\circ} 15$, \\ 2900-319 Setúbal, Portugal; vasco.silva@mun-setubal.pt \\ * Correspondence: jcrf@fct.unl.pt (J.C.F.); rmc.monteiro@fct.unl.pt (R.M.)
}

Citation: Ferreira, J.C.; Monteiro, R.; Silva, V.R. Planning a Green Infrastructure Network from Theory to Practice: The Case Study of Setúbal, Portugal. Sustainability 2021, 13, 8432. https://doi.org/10.3390/ su13158432

Academic Editor:

Carlos Oliveira Cruz

Received: 19 June 2021

Accepted: 22 July 2021

Published: 28 July 2021

Publisher's Note: MDPI stays neutral with regard to jurisdictional claims in published maps and institutional affiliations.

Copyright: (c) 2021 by the authors. Licensee MDPI, Basel, Switzerland. This article is an open access article distributed under the terms and conditions of the Creative Commons Attribution (CC BY) license (https:// creativecommons.org/licenses/by/ $4.0 /)$.

\begin{abstract}
Green infrastructure is a strategically planned network of natural and semi-natural areas that are designed and managed to deliver a wide range of ecosystem services. It incorporates green and blue spaces and other physical features in terrestrial and marine areas. Despite the increase of green infrastructure planning in several regions of the world, such as Europe and North America, there is still a complexity and diversity associated with the concept of green infrastructure that influences the variance in approaches of green infrastructure planning. This research proposed a multi-criteria method that was organized in four steps for designing a green infrastructure for the municipality of Setúbal (Portugal) that efficiently integrated the ecological and social components in the planning and policymaking processes, as well as green infrastructure planning principles. The results show a green infrastructure that comprised around $91 \%$ of the territory of the case study, organized into two systems: the fundamental green infrastructure, which was related to the areas whose ecological interests were more favorable, and the urban green infrastructure, which aimed to enhance and intensify ecological processes in built-up areas. This approach focused on the protection of ecological functions, the preservation of the cultural and natural heritage, and the prevention of risks at a local level; it also followed several green infrastructure planning principles, namely, connectivity, multifunctionality, diversity, integration, and applicability.
\end{abstract}

Keywords: green infrastructure; ecosystem-based management; sustainable spatial planning; multiscale; ecosystem services; Setúbal

\section{Introduction}

The concept of green infrastructure has attracted special attention in both academia and planning policy/practice since it emerged in the 1990s [1-3]. In fact, its concept has evolved in the last few decades and can be perceived differently according to the context in which it is used [4]. For some, it may involve natural areas and ecosystems that provide ecological benefits, and for others, it may be engineered structures for stormwater management, for example [4,5]. Nevertheless, green infrastructure is perceived nowadays as a strategically planned and interconnected network of natural and semi-natural areas with other environmental features that are designed and managed to deliver a wide range of benefits to people and wildlife (ecosystem services) [4,6,7]. These areas may include a variety of green and blue spaces, such as parks, open spaces, playing fields, pocket spaces, lakes, river streams, small incidental green spaces, and neighborhood gardens, that are linked by tree-lined streets and waterways around and between urban areas $[8,9]$.

As a strategic spatial planning instrument, green infrastructure can respond to several societal changes and challenges as a way of providing several social, environmental, and economical benefits [10-12]. The environmental benefits include climate change mitigation and adaptation that contribute to a decrease in flooding risks and an increase in thermal 
performance of buildings, street temperature regulation, carbon storage increase, and maintenance of freshwater quality and supply [9,11-13]. Additionally, green spaces provide habitats for a range of species and, consequently, contribute to biodiversity enhancement, as well as wildlife conservation [11]. Social benefits relate to the exposure of residents to urban green spaces and are usually associated with recreational and cultural activities, such as sports, relaxation, and social interactions $[11,12,14]$. These benefits have a positive impact on people's health and well-being $[11,14,15]$ and help to increase the connectivity between urban and rural areas and, therefore, local distinctiveness, social inclusion, and a sense of community $[1,3]$. Economic benefits are usually linked to an increase in property values, which helps to attract and retain high-value industries, new business start-ups, entrepreneurs, and skilled workers [1,14]. Other economic benefits include a decrease in health care expenses [15] and an increase in tourism [14]. These benefits reinforce the potential that green infrastructure has in contributing to achieving sustainable development and a fair quality of life [16].

Green infrastructure planning and management play a crucial role in the process of establishing the goals and priorities of the communities as a whole, whether at national, regional, or local levels. This allows for the reduction of uncertainty and risks, as well as guarantees that the population has access to all the resources and services and that all its needs are fulfilled, both ecologically and socially [17]. Although the concept of green infrastructure is relatively well known among practitioners and policymakers, green infrastructure planning is still seen as a distinct subset of this topic $[2,18,19]$. In fact, according to Rall et al., green infrastructure planning represents "an advancement of socially and aesthetically-oriented green space planning and ecological planning, both of which are implemented in spatial planning but are often considered by separate governmental entities and policies focusing on singular issues such as recreation, water or biodiversity" [20]. For that reason, today's green infrastructure planning not only aims at creating, designing, and developing a network of green (and blue) and natural spaces in urban and rural environments but also involves implementing and managing different nature-based solutions through the application of certain planning processes, approaches, and policy themes [2], which guarantee the provision of ecosystem services, as previously stated, such as ecosystem-based management. The ecosystem-based management concept, which was introduced in the late 1940s, attempts to integrate biophysical and social dimensions of human activities with science-based approaches to manage natural resources that aim to sustain the health, resilience, and diversity of ecosystems while allowing for sustainable use by humans of the goods and services they provide [21-23]. Broadly speaking, ecosystem-based management is not simply substituting man-made protection and management infrastructures with natural ecosystems with similar functions [24], it is an integrated approach of management that considers the entire ecosystem, linkages across systems and disciplines, and the cumulative impacts of different human sectors [22]. The successful planning and implementation of green infrastructure involve, in many cases, the preservation of the connectivity and dynamics of natural ecosystems by mimicking their natural functioning [24]. Thus, the development of integrative, ecosystem-based, cohesive, and comprehensive green infrastructure plans must consider the best practices and principles (e.g., multifunctionality, connectivity, diversity) but also address the difficult challenges that communities will face in the future (e.g., climate change adaptation and mitigation, biodiversity protection, social cohesion) $[17,25]$.

Although there is considerable literature on ecosystem-based management and green infrastructure planning, there is still a complexity and diversity associated with the concept of green infrastructure that influences the variance in approaches, implementation strategies, and structural/institutional support at the national and sub-national scales of green infrastructure planning $[19,26,27]$. Because of this, different green infrastructure planning approaches have been followed across the world, with a special focus on Europe and North America $[18,27,28]$. Whilst in Europe, green infrastructure emphasizes networks of green space that provide multiple ecosystem services, in North America, the focus is 
predominately on water systems and ecological resource management [27,29]. Asia, and especially China, has also seen an increase in research regarding green infrastructure; however, because green infrastructure is a relatively new concept in this continent, there are still no guidelines or laws for green infrastructure planning at the national level [30]. Other regions, such as Africa or Latin America, still struggle to follow green infrastructure planning trends due to a misunderstanding or undervaluation of the benefits associated with such infrastructure, as well as a lack of national and local governments' interest [31,32].

In this paper, we suggest a feasible and replicable multi-step framework to help plan, develop, and implement green infrastructure based on an ecosystem-based management approach. With this proposed methodology, we intended to efficiently integrate the ecological and social components in the land-use planning and policymaking processes. In addition, the innovation of the method also relied on the implementation of the green infrastructure at different spatial scales. Along with the description of the study area and the explanation of why this area was chosen, the subsequent section introduces the general framework that was used for the design of the green infrastructure. Section 3 presents the results of the applied methods, and then we discuss the interpretation of the results and analyze the strengths and weaknesses of our green infrastructure framework (Section 4). Section 5 provides reasons for further research and concludes the analysis.

\section{Materials and Methods}

\subsection{Study Area}

Setúbal $\left(38^{\circ} 31^{\prime} 28^{\prime \prime} \mathrm{N}, 8^{\circ} 53^{\prime} 35^{\prime \prime} \mathrm{W}\right)$ is a municipality that is located in the Lisbon Metropolitan Area, Portugal, $25 \mathrm{~km}$ south of Lisbon. Setúbal has an administrative area of $230.33 \mathrm{~km}^{2}$ and consists of five parishes-Azeitão, Setúbal (S. Julião), Setúbal (S. Sebastião), Gâmbia-Pontes-Alto-da-Guerra, and Sado. According to Census 2011, Setúbal had a population of 121,185 inhabitants and a population density of 526.14 persons $/ \mathrm{km}^{2}$; however, this number is expected to have decreased in the last decade. The municipality is bordered in the south by the Sado Estuary and the Atlantic Ocean, also in the south, as shown in Figure 1.

Setúbal is a Mediterranean climate area, with average annual temperatures of approximately $16.6^{\circ} \mathrm{C}$ and average annual precipitation of $538 \mathrm{~mm}$. Summers are usually hot and dry, and the average maximum temperature is around $29^{\circ} \mathrm{C}$ in August. Winters are usually mild and rainy, with high humidity. The average minimum temperature is around $8^{\circ} \mathrm{C}$ in January and December has the highest rainfall, with an average of $81 \mathrm{~mm}$ [33].

The river network of the municipality has a total extension of $796.3 \mathrm{~km}$, and most of the rivers in the administrative area flow into the Sado river/estuary, except for the rivers in Azeitão. The terrain of the municipality is relatively flat in the urban center and the west due to the presence of the Sado estuary; however, there is a mountain range and hills in the east. Because of this, Setúbal's animal and plant resources are very abundant and the municipality encompasses two important protected areas-Arrábida Natural Park (17,650 ha) and Sado Estuary Natural Reserve (23,160 ha). Both areas are protected by law and belong to the Natura 2000 Network, which makes them very sensitive to human occupation.

The municipality of Setúbal has numerous infrastructures and facilities located along its coastline, which are mainly linked to the port areas, industry, and commercial activities associated with fishing, but also with services and tourism [34]. Therefore, Setúbal assumes an important economic hub for the Lisbon Metropolitan Area and Portugal [35]. 

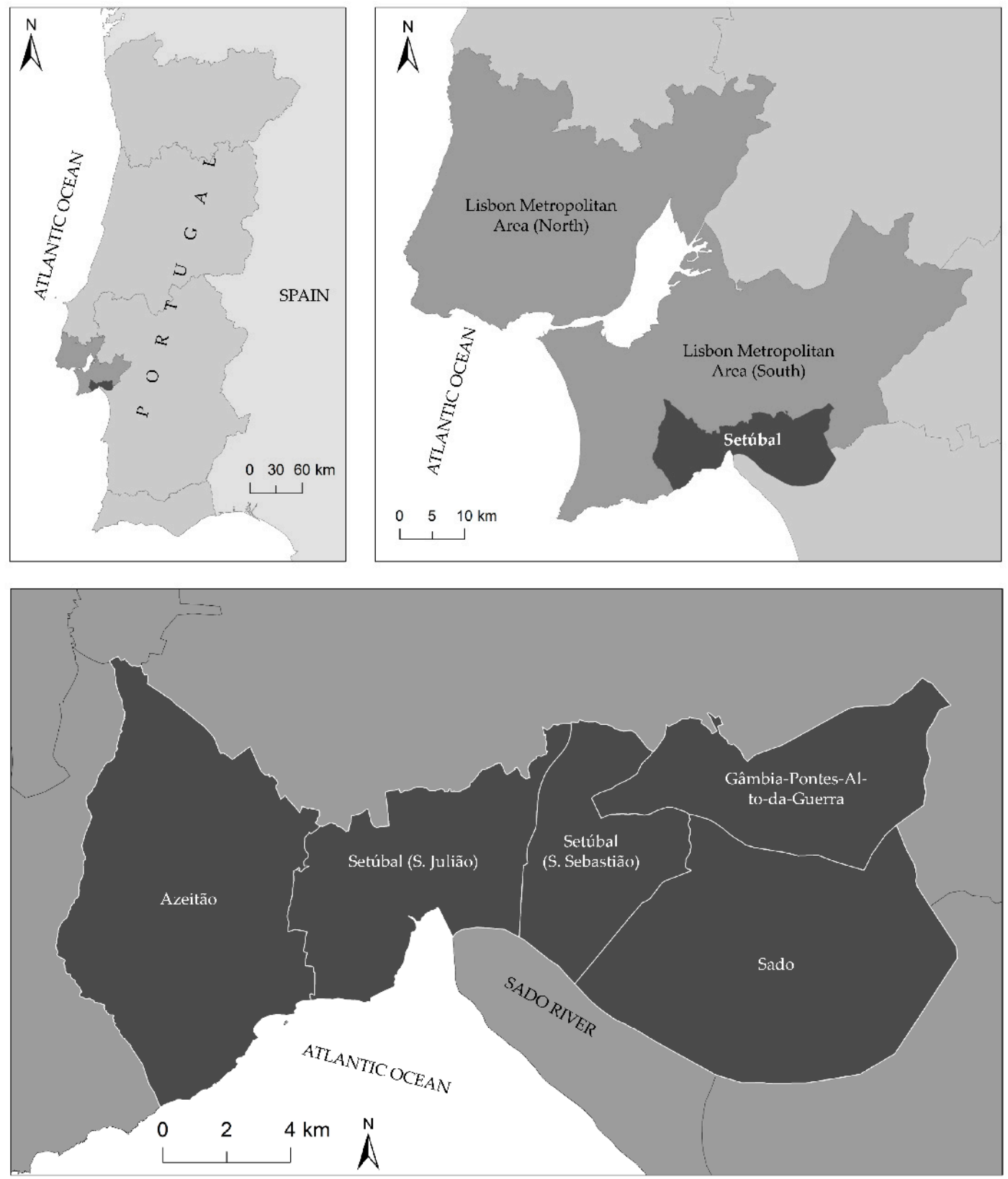

Figure 1. Geographic location and boundaries of the municipality of Setúbal (data source: Carta Administrativa Oficial de Portugal-CAOP 2020).

The municipality of Setúbal reconciles urban and rural characteristics in its administrative borders, which gives it great territorial complexity and, together, represents a diversity of natural and semi-natural areas, as well as a diverse biophysical and socio-economic gradient. Not only the municipality of Setúbal possesses an urban center of great economic importance, as previously stated, but its urban area is also framed by two protected areas with very distinct characteristics that provide high ecological importance to the territory. In addition to this, Setúbal is a coastal municipality, which makes it extremely vulnerable to climate risks, especially floods, overtopping, tsunamis, and erosion.

The same factors that make the municipality of Setúbal so unique also pose additional challenges in terms of planning and land-use. At the same time, immaterial values, such as landscape beauty, recreation, sense of place, and inspiration, are seen as increasingly important for the population of Setúbal, which increases the complexity of green infrastructure planning. For these reasons, Setúbal was chosen as a case study for the development of a green infrastructure framework based on an ecosystem-based management approach. 


\subsection{General Framework for the Green Infrastructure Design}

One of the main issues with green infrastructure planning is that there is still no defined methodology to guide its development, as well as its implementation approaches. This often makes it difficult for the municipalities, and especially urban planners, to develop an instrument that encompasses all dimensions of sustainability, as well as the green infrastructure planning principles, since each municipality has the autonomy to choose which elements should be included in the green infrastructure.

In this paper, we propose a multi-criteria methodology for designing the green infrastructure at a local level based on the methodology developed by Cunha and Magalhães [36], as well as previous planning works developed for Setúbal by the Department of Environmental Sciences and Engineering of the NOVA School of Sciences and Technology of NOVA Lisbon University, in close collaboration with the Urban Planning Division of the Setúbal City Council.

The method consists of the identification and mapping of the areas to guarantee the ecological functions of the municipality of Setúbal, as well as the development of management measures to help the implementation of the green infrastructure. The approach we used for mapping the green infrastructure, similar to Cunha and Magalhães [36], goes beyond the traditional methods of green infrastructure delimitation that only take into account the habitats and corridors that are not related to the physical system. However, our approach goes further; besides the ecological intrinsic landscape attributes of the territory, we also included the land use in the delimitation of the green infrastructure. The method is composed of a sequence of analyses and evaluations that are driven by a geographical information system supported assessment of several elements. As is shown in Figure 2, the methodological process was organized into four main phases, as follows: (i) territorial characterization, (ii) core variables evaluation, (iii) definition of the ecological structure, and (iv) update and concert.

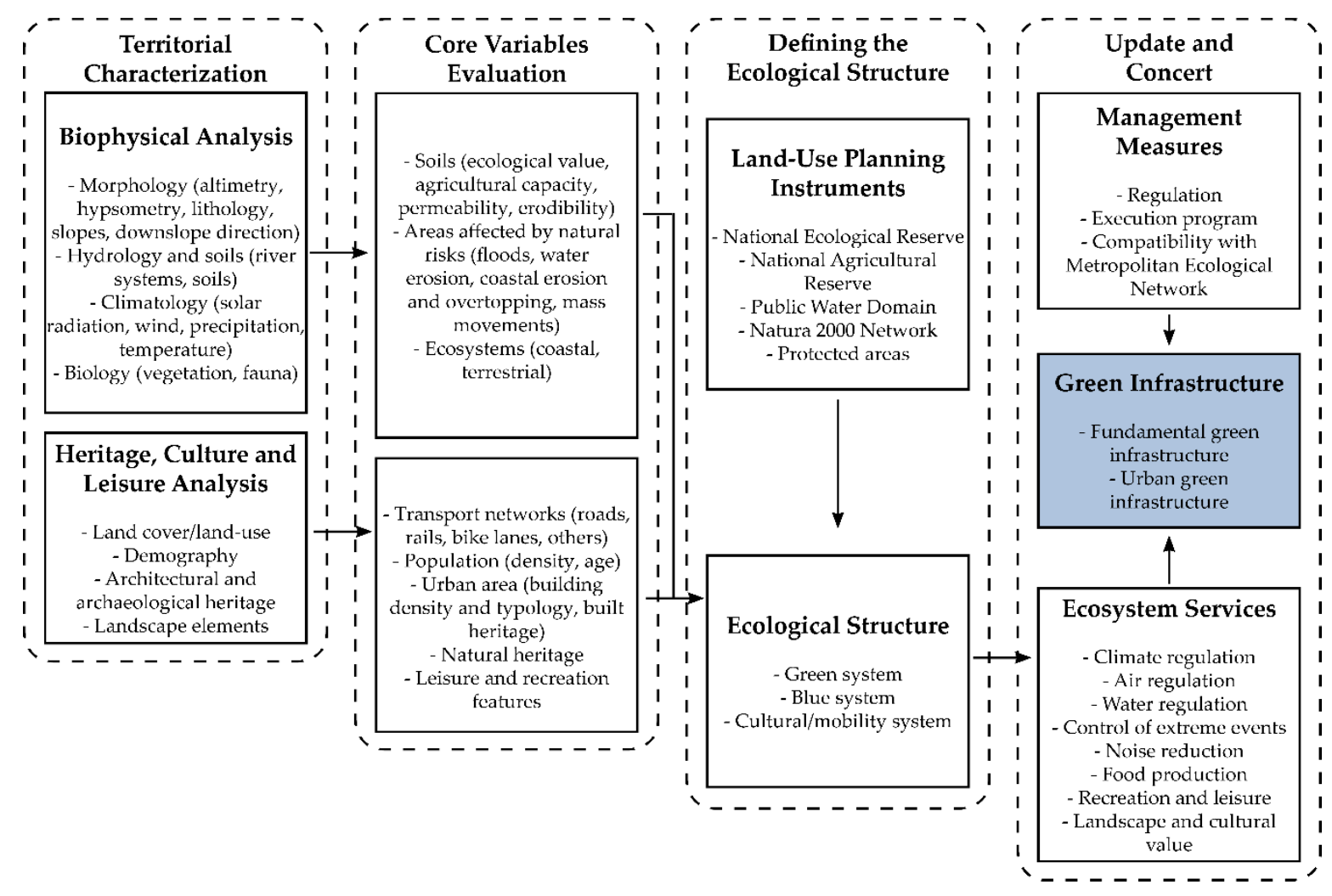

Figure 2. Overview of the methodological approach for the development of the green infrastructure of Setúbal. 
The first phase of the methodology consisted of a territorial characterization of the municipality of Setúbal, which was composed of a biophysical analysis, as well as a survey and analysis of the existing cultural, educational, and leisure heritage. Regarding the biophysical analysis, the considered elements were grouped into four main domains: morphology, which included the altimetry, hypsometry, lithology, and slopes and downslope direction analysis; hydrology and soils, which included the river streams and types of soil; climatology, which included the solar radiation, wind, precipitation, and temperature; and finally, biology, which included vegetation and fauna [36]. All these elements were obtained and analyzed through a geographical information system, similar to other studies $[37,38]$. As for the cultural, educational, and leisure heritage analysis, the following variables were considered: land cover and land use, demography, architectural and archaeological heritage, and landscape elements. Some of these elements relied, once again, upon geographical information systems; however, others were present in previous reports and studies conducted by the municipality.

From the previous analysis results, a set of core variables that supported the spatial delimitation of the ecological structure was developed (third phase). The biophysical analysis contributed to the development of the following variables, organized into three groups: soils, which included the ecological value, agricultural capacity, permeability, and erodibility; areas affected by natural risks, which included floods, water, and coastal erosion, overtopping, and mass movements; and finally, ecosystems, including coastal and terrestrial. From the heritage, cultural, and leisure analysis results, the following variables, organized into five groups, were produced: transport networks, which included roads, rails, bike lanes, and other important networks; population, density, and age; urban area, which included building density and typology, as well as the built heritage; natural heritage; and leisure and recreation features.

The third phase consisted of defining the areas with greater ecological interest, that is, the ecological structure, and identifying which categories would be part of it, as seen in Figure 3. For this task, the variables that were identified previously served as the foundation for the definition of the ecological categories, which were grouped into three systems-green, blue, and cultural/mobility systems. The green system consisted of all areas and corridors with vegetation, mostly intended for plant production, and the blue system included all areas and territories responsible for the circulation and accumulation of water. The cultural/mobility system was intended to safeguard the cultural elements of the municipality, as well as to promote sustainable mobility.

In addition to the core variables, in the third phase of the methodological process, the easements and conditions for land-use planning that were implemented at that moment were integrated into the ecological structure, which contributed to the definition of the categories presented in Figure 3. Those easements and conditions were the National Ecological Reserve (REN), National Agricultural Reserve (RAN), Public Water Domain (DPH), and Natura 2000 Network. The REN integrates all areas requiring special protection due to their ecological sensitivity or exposure and their vulnerability to natural hazards. This includes coastal and river areas, aquifer recharge areas, and steep-slope areas for erosion protection [36]. The RAN and DPH aim to protect soil and water resources, respectively, and the Natura 2000 Network aims to ensure the long-term survival of Europe's most valuable and threatened species and habitats, which are listed under both the Birds Directive and the Habitats Directive. Both the protected areas (Arrábida Natural Park and Sado Estuary Natural Reserve) and their respective land-use plans were also considered in this process. 


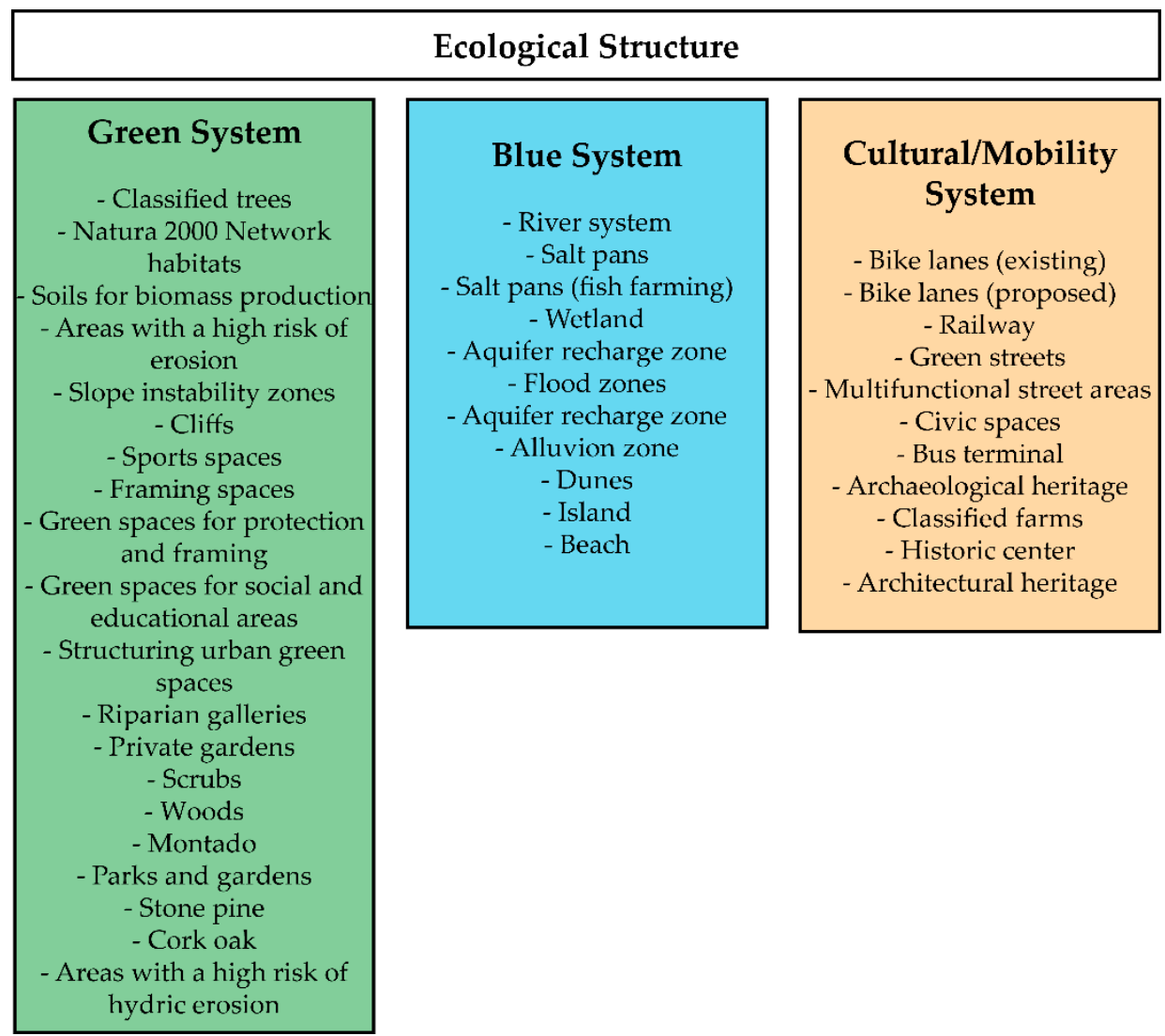

Figure 3. Categories considered in the ecological structure of Setúbal, grouped into the green, blue and cultural/mobility systems.

The final phase of this process included the development of management measures and the integration of ecosystem services in the green infrastructure plan. As for the first one, the Metropolitan Ecological Network (REM) and respective guidelines were integrated into the municipality's green infrastructure proposal. REM is a network that is designed for the Metropolitan Area of Lisbon and consists of ecological corridors and vital and structuring areas to improve ecological functions, the environment, and the quality of life of the region. After that, a set of regulatory measures and actions, which were specifically designed for the green infrastructure implementation, were considered during the planning process of the Master Plan of Setúbal. In this part of the process, several meetings were organized with the planning team, and different and innovative strategies were considered, which were compiled and included in the green infrastructure plan afterward. In addition, a portfolio of projects and investment actions was proposed for the implementation of the green infrastructure through innovative, multifunctional, and diversified solutions, which are intended to be developed in the territory at different spatial scales. To conclude this process, a set of eight ecosystem services were identified by a group of specialists, together with the green infrastructure planning team. These services were considered the most relevant for the municipality and they are to be incorporated in the green infrastructure. The ecosystem services are climate regulation, air regulation, water regulation, extreme events control, noise reduction, food production, recreation and leisure, landscape, and culture. These ecosystem services were selected based on the categories of the ecological structure defined in the previous phase and grouped into the green, blue, and cultural/mobility systems.

This process resulted in the green infrastructure of Setúbal, which was organized into two main structures: the fundamental green infrastructure, which included the areas essential for the functioning of natural systems; and the urban green infrastructure, which aimed to enhance and intensify ecological processes in built-up areas. 


\section{Results}

The green infrastructure plan for Setúbal was developed based on the ecological values of Setúbal (ecological structure), which are incorporated in all the areas with crucial ecological functions, including natural green areas, water bodies, soils with high agricultural value, permeable areas, and landscape and recreational areas. These areas aimed to contribute to the sustainability of the building structure, promote biodiversity, and contribute to the physical stability and ecological sustainability of the municipality. Although the identification of these areas is required by law in Portugal, there are no guidelines for its identification, which gives municipalities the freedom to design the ecological structure as they wish. The ecological areas of Setúbal were organized into three systems, as previously stated: green, blue, and cultural/mobility, as seen in Figure 4.

The green infrastructure of Setúbal is an ecosystem-based management planning tool that recognizes the territorial ecological systems and sustainably guides the occupation and transformation of the territory. Similar to the ecological structure, it consists of a set of areas that contribute to the ecological balance and protection and conservation of natural resources; however, the green infrastructure goes further and guarantees the enhancement of the landscape of rural and urban spaces, comprising around $91 \%$ of the municipality of Setúbal. For this reason, the green infrastructure of Setúbal was organized into two main structures: the fundamental green infrastructure and the urban green infrastructure (Figure 5). The former was related to the areas whose ecological interests are more favorable, which included the areas essential for the functioning of natural systems, in particular the ones regarding water circulation, climate regulation, and air circulation, and whose protection is indispensable for the sustainable functioning of the territory. This structure-which encompasses $81.7 \%$ of the total territory-aimed to create a connection between urban areas and the surrounding landscapes by framing the road network and pedestrian circulation and the larger and more ecological green spaces. The fundamental green infrastructure favors continuous systems of production, protection, and recreation, including the areas where construction is not allowed and the soil cannot become waterproofed.

The urban green infrastructure consists of an urban-scale structure that aimed to enhance and intensify ecological processes in built-up areas. This urban green infrastructure is a structure of protection, climate regulation, and biophysical support that is integrated into the urban fabric and is composed of "artificial" elements, resulting from anthropic actions and with a "complementary connectivity," such as parks and gardens. The urban green infrastructure encompasses $9.5 \%$ of the territory and it is composed mainly of the urban and peri-urban areas of the municipality (Setúbal and Azeitão).

The green infrastructure of Setúbal has as its main objective the promotion of the sustainable development of the territory through the compatibility of urban and rural uses with the integration and valorization of the natural, cultural, and landscape heritage, as well as the requalification and regeneration of the spaces of high environmental value. This objective is divided into three major groups, with each group having specific goals: the guarantee of ecological functions, the preservation of the cultural and natural heritage, and the development of national and sectorial strategies at the local level (Table 1). 


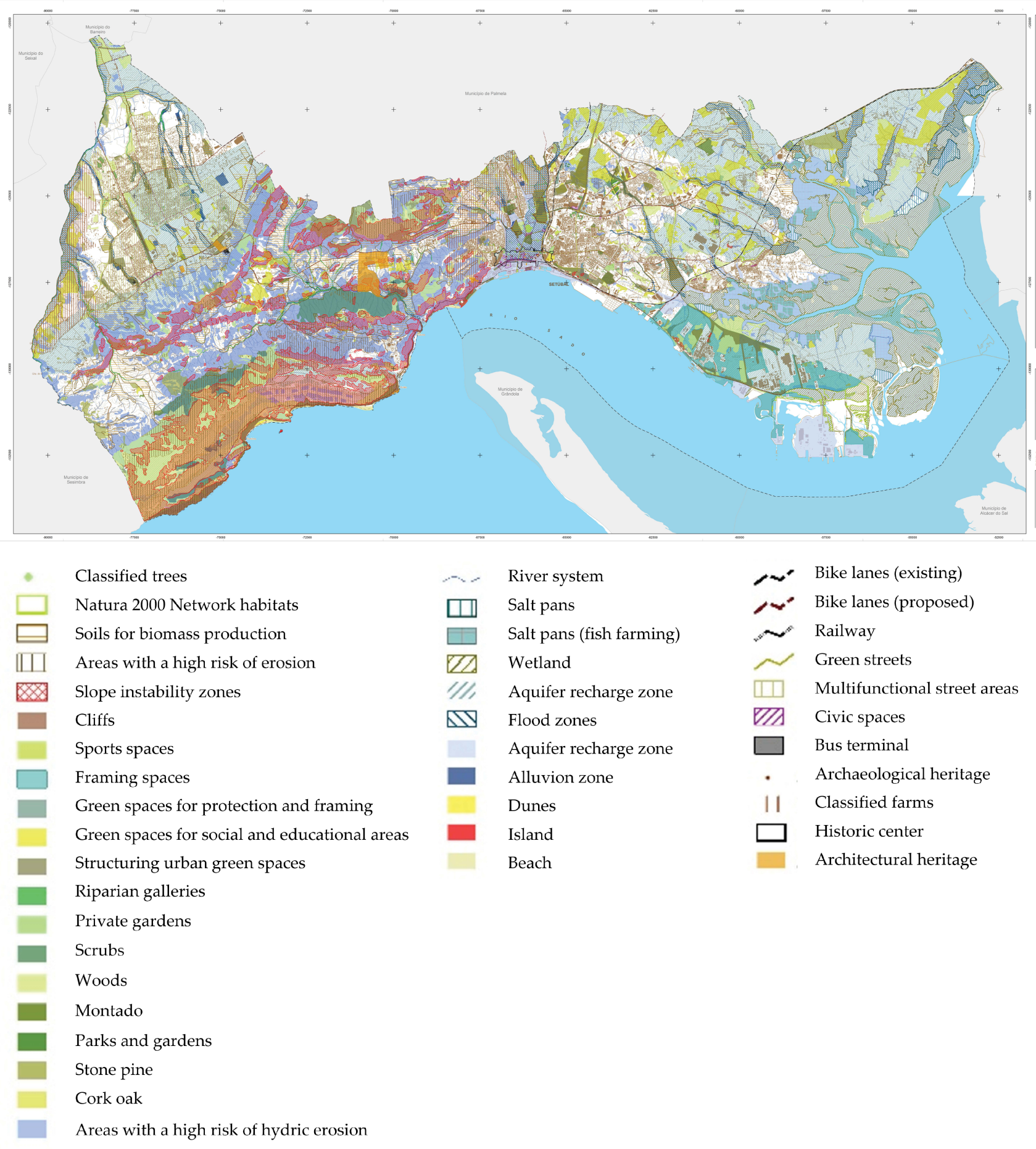

Figure 4. Ecological areas of Setúbal that were considered for the development of the green infrastructure (ecological structure). 


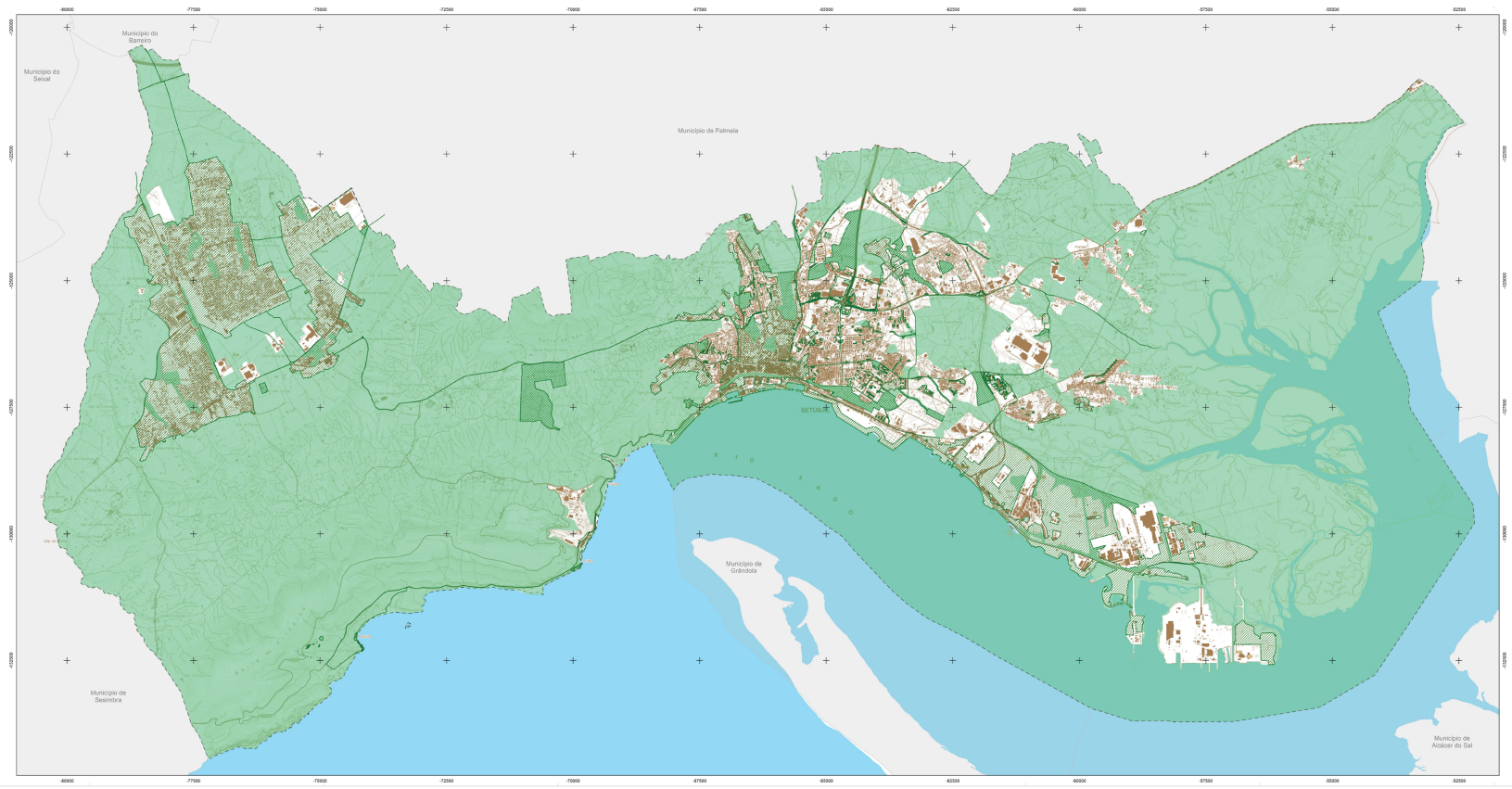

Fundamental green infrastructure

27 Urban green infrastructure

Figure 5. The green infrastructure of Setúbal (fundamental and urban).

Table 1. Objectives of the green infrastructure of Setúbal.

\begin{tabular}{|c|c|c|c|c|}
\hline & Guarantee of Ecological Functions & & $\begin{array}{c}\text { Preservation of the Cultural and } \\
\text { Natural Heritage }\end{array}$ & $\begin{array}{l}\text { Development of National and } \\
\text { Sectorial Strategies }\end{array}$ \\
\hline - & $\begin{array}{l}\text { Safeguarding the municipality's } \\
\text { endogenous natural resources } \\
\text { Promote the articulation between the } \\
\text { urban and natural environment through } \\
\text { green corridors } \\
\text { Promote development by ensuring } \\
\text { environmental quality }\end{array}$ & - & $\begin{array}{l}\text { Preserve landscape points of interest } \\
\text { and unique scenic spots } \\
\text { Valuing the built and natural heritage } \\
\text { Fostering productive landscapes }\end{array}$ & $\begin{array}{l}\text { - } \quad \begin{array}{l}\text { Promote sustainable mobility } \\
\text { - }\end{array} \quad \begin{array}{l}\text { Promote local strategies for adapting to } \\
\text { climate change }\end{array} \\
\text { Promote local strategies for reducing } \\
\text { natural and technological risks }\end{array}$ \\
\hline
\end{tabular}

As an environmental planning instrument, the green infrastructure of Setúbal has a regulatory feature that aims at the protection of natural resources, a propositional dimension that aims at the regeneration of environmental systems, and even a multiscalar factor that integrates itself into the other spatial planning instruments with higher hierarchy (regional, national plans). In addition to safeguarding the existing ecological systems, the green infrastructure of Setúbal also allows for the creation of new ecological units that can enhance the continuity of the territory, either through the network of municipal green corridors and large inter-municipal ecological corridors or at a more local level, with the creation of protected green areas.

Although the ecological structure and the green infrastructure may briefly seem similar, the truth is that the two instruments are quite different. Whereas the first only identifies the areas that are more important in terms of ecological functions, the latest aggregates all these areas into one, establishing a regional and an urban dimension. Besides this, the green infrastructure of Setúbal also considers the provision of ecosystem services. In fact, green infrastructure is usually defined as an "interconnected network of multifunctional green spaces that are strategically planned and managed to provide a range of ecological, social, and economic benefits (ecosystem services)" [3,12,15]. 
Ecosystem services are present in the green infrastructure of Setúbal and correspond to goods, services, and benefits of a material or immaterial nature that come from functional ecosystems. Ecosystem services are crucial for the functioning of terrestrial life and contribute, directly and indirectly, to the well-being of the population by having a substantial economic value at a global level. The municipality of Setúbal, due to its unique characteristics, namely, the great landscape diversity and its strategic location, provides a variety of ecosystem services that contribute to the increase of the territory's resilience and sustainability. Climate regulation, air regulation, water regulation, control of extreme weather events, noise reduction, food production, recreation and leisure, and landscape and cultural value were the ecosystem services identified by the planning team as the ones that were more relevant for the municipality and hence were incorporated into the green infrastructure. These ecosystem services are provided at different scales-local and municipal-and are assured by the existence of different ecosystems and land uses in the municipality of Setúbal; furthermore, these services directly depend on the quantity and quality of the green infrastructure.

The provision of these ecosystem services was a priority of the municipality, and some technical and legal parameters were proposed to guarantee the implementation of the green infrastructure. Fiscal and urban incentives were proposed for projects that contribute to the implementation of the municipal territorial development strategy to be operationalized under municipal regulations. Additionally, the execution program proposed a portfolio of projects and investment actions to implement the green infrastructure and enhance ecosystem services provision through innovative, multifunctional, and diversified solutions, which will be developed in the territory at different spatial scales, from the building to municipality levels (Figure 6).

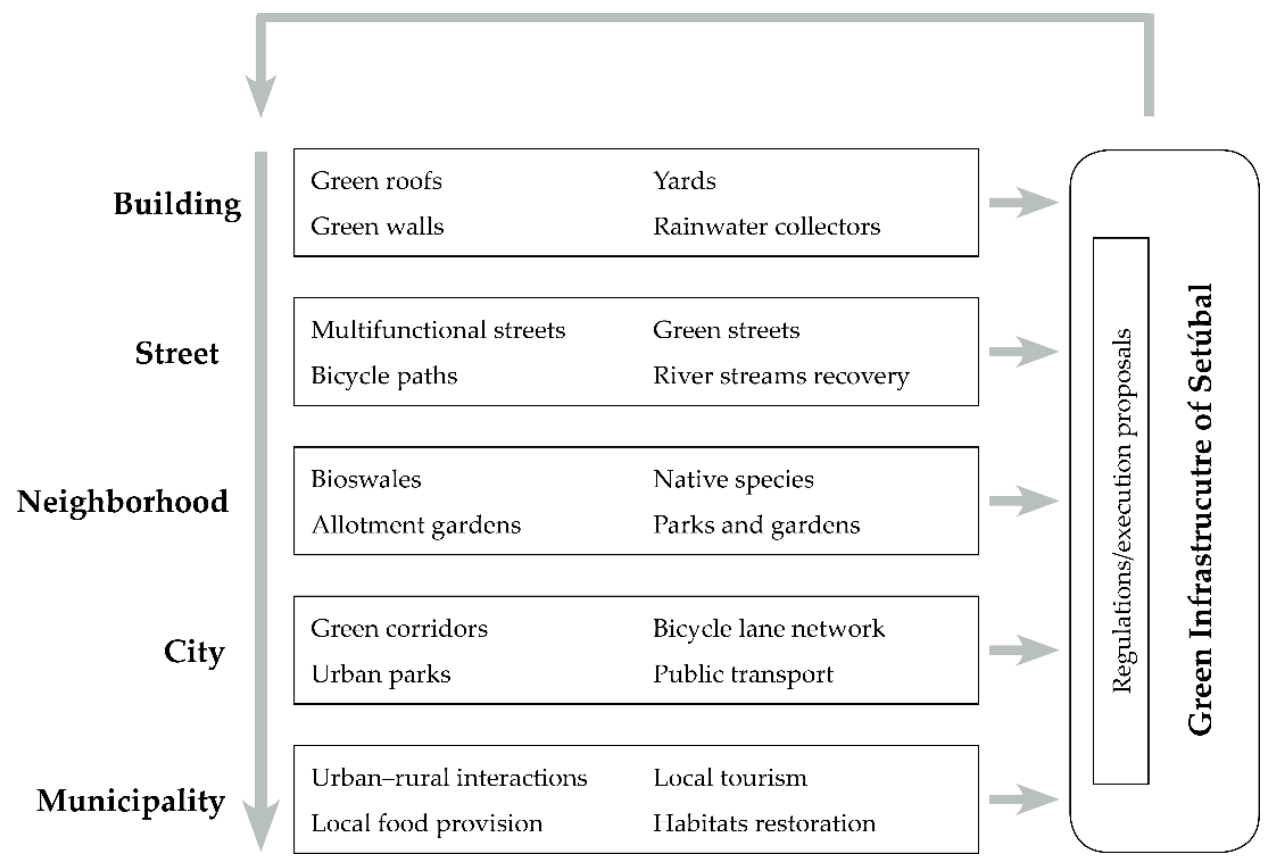

Figure 6. Proposed execution program and investment actions to implement the green infrastructure of Setúbal (some examples).

The execution program presented in Figure 6 shows only some examples of green infrastructure projects that can be implemented at various scales. Although in the figure, each scale only shows independent and separate components for simplification purposes, the broader scales also contain the components identified in the smaller scales. The larger the scale is, the more components of green infrastructure are involved in the planning process. 


\section{Discussion}

As discussed previously, one of the main issues that municipalities face regarding green infrastructure planning is the nonexistence of proper guidelines to guide practitioners during its development and implementation. Despite some authors having proposed some green infrastructure planning principles to help practitioners and urban planners during the development, management, and implementation of green infrastructure $[3,25,29,39]$, the fact is that there are some doubts regarding this issue. Therefore, to manage this problem, in this research, we proposed a methodology to develop a green infrastructure, with the municipality of Setúbal as a case study. In this section, we discuss the highlights and fragilities of this approach, as well as the lessons other municipalities and urban planners, and practitioners in general, can learn from Setúbal's experience.

One of the strengths of the methodology proposed in this paper is the multi-step approach to the green infrastructure planning process, which was based on reliable, current, and locally relevant knowledge. A comprehensive collection of the existing knowledge on ecosystems and their condition, as well as the cultural heritage of the municipality, resulted in the inclusion of both biophysical and sociocultural indicators, similar to the study of Caparrós et al. [37]. The inclusion of these indicators was crucial to guaranteeing that the green infrastructure responded to the environmental and cultural needs of the municipality, as well as its inhabitants. Because of this inclusion, the green infrastructure of Setúbal is prepared not only to preserve and protect the territory's ecological functions, but also to preserve the cultural and natural heritage and to promote the development of strategies that contribute to sustainability (e.g., promotion of sustainable mobility), which is something that distinguishes the green infrastructure presented in this paper from other ones. Although the ecological functions are often the main focus of green infrastructure planning, social benefits, recreational activities, and cultural aspects are also very important criteria in the planning interventions [3]; however, they are usually dismissed [40,41]. The cultural and mobility components of the green infrastructure contribute to increasing the connectivity between urban and rural areas, and therefore, local distinctiveness, social inclusion, and sense of community.

Another strength of this green infrastructure is the relevance given to water bodies and water regulation ecosystem services during its development and implementation. As a coastal municipality, Setúbal is extremely vulnerable to flood events, overtopping, and erosion, which raises concerns for civil protection, policy practitioners, and the general community. Therefore, the worries regarding water circulation were a priority for the urban planners during the design of the green infrastructure. If we consider the city of Setúbal, the soil impermeabilization and the lack of vegetation have serious impacts on the water cycle, especially on days with intense rainfall, as they lead to a decrease in water infiltration and, consequently, to an increase of surface runoff and soil erosion. Flood events, which are common in Setúbal almost every winter [42-44], cause extreme damage throughout the city, economic losses, and put citizens at risk. The green infrastructure presented here is aimed toward the protection of green spaces, which are permeable soils that allow for water infiltration and guarantee the recharge of the aquifer, as well as the reduction of surface runoff and, consequently, the reduction of flood events.

The design of this methodology follows some crucial green infrastructure principles that contribute to biodiversity conservation and ecosystem services enhancement. Along with the connectivity, as previously discussed, one of the most obvious green infrastructure planning principles included in this approach is multiscale. This principle refers to the different scales that the green infrastructure can be planned for, from a building perspective to a more regional and integrated perspective, which includes landscape interactions and larger natural areas [3]. Our proposal focused mainly on two levels: urban and municipal. However, we also proposed an execution program that recommends a portfolio of projects and investment actions to enhance the provision of ecosystem services at different scales, from the building to municipality levels. In fact, the inclusion of this execution program shows how innovative and action-driven the green infrastructure of 
Setúbal is when compared with similar proposals that only focused on the development of the green infrastructure but lack actual proposals for its implementation $[41,45]$. These actions are part of an ecosystem-based management approach that was developed to help the implementation of the green infrastructure of Setúbal, which reinforces other green infrastructure planning principles, namely, multifunctionality, diversity, integration, and applicability [3], similar to another study in Warsaw [46].

Although our approach has some strengths and innovates regarding several points when compared with other methods, there are still some limitations to this study. During the development of the green infrastructure of Setúbal, ecosystem services were considered during the planning process; however, these were selected purely based on academic and practitioners' knowledge, disregarding the population's perception/insight. In fact, in the study conducted by Rall et al. [20], the authors state that public participation can enhance green infrastructure planning, implementation, and management and contribute toward a more sustainable urban development. However, in our study, the citizens were not invited to participate in the development of the green infrastructure, which could have helped the development team to improve its design/implementation actions. The green infrastructure was only made available for public discussion at the end of the process, as is required by Portuguese law.

In addition to the lack of public participation, the ecosystem services were not mapped as part of the infrastructure planning. According to Ramyar et al. [47], studying and mapping ecosystems services could help to make practical and integrated decisions that simultaneously meet the different ecological, social, and economic needs of municipalities. Additionally, spatial-social patterns of ecosystem services could also highlight potential areas to be considered when designing the green infrastructure or proposing plan interventions.

\section{Conclusions}

In recent years, many studies were conducted regarding green infrastructure planning, implementation, and management. However, due to the novelty of the term, there are still no specific guidelines (at national or European levels) to help practitioners to develop and implement green infrastructure. For this reason, by using a multi-step methodology, this study constructed a multiscale and multifunctional green infrastructure from the perspectives of ecological resources and cultural heritage. It is a new and feasible approach for identifying the areas with crucial ecological functions and socio-cultural benefits that also consider landscape enhancement of rural and urban spaces and multiple ecosystem services.

The green infrastructure planning method developed in our research focuses on the protection of ecological functions, the preservation of cultural and natural heritage, and the prevention of risks at a local level. Although there were several recent studies regarding green infrastructure planning, we believe our method is innovative and can be useful for urban planners, practitioners, and policymakers. The method can be easily replicable by other researchers and developers, as it is proposed in this paper, or can be combined with other potential functions that are based on the local context analysis of local authorities involved in green infrastructure planning.

The protection and implementation of the green infrastructure can ensure the protection of natural ecosystems and guide sustainable development in Setúbal in the future, as well as influence future green infrastructure projects in the neighboring municipalities and the metropolitan area. Hence, flexible environmental protection measures and ecosystem-based management approaches, such as environmental plans at local, municipal, and regional scales, should be used to maintain, improve, and spread this network. As for the next steps, the green infrastructure needs a transition methodology for the urban management process, which will allow for the effective implementation of nature-based solutions and the protection and enhancement of the respective ecosystem services. This process is an important challenge for the municipality of Setúbal; to overcome this chal- 
lenge, the development of some multi-actor sessions with the involvement of the local community "living labs" is planned for the co-construction of operational solutions for the implementation of the green infrastructure. In addition, a literacy program regarding green infrastructure and ecosystem services is expected to be developed in parallel to these sessions to improve the engagement of the community in the management and maintenance of the green infrastructure.

Author Contributions: Conceptualization, methodology, and writing were carried out by J.C.F., R.M., and V.R.S. All authors read and agreed to the published version of the manuscript.

Funding: The authors acknowledge and thank the support given to MARE by the Portuguese Foundation for Science and Technology (FCT) through the strategic projects UIDB/04292/2020.

Conflicts of Interest: The authors declare no conflict of interest.

\section{References}

1. Wright, H. Understanding Green Infrastructure: The Development of a Contested Concept in England. Local Environ. 2011, 16, 1003-1019. [CrossRef]

2. Davies, C.; Lafortezza, R. Urban Green Infrastructure in Europe: Is Greenspace Planning and Policy Compliant? Land Use Policy 2017, 69, 93-101. [CrossRef]

3. Monteiro, R.; Ferreira, J.C.; Antunes, P. Green Infrastructure Planning Principles: An Integrated Literature Review. Land 2020, 9, 525. [CrossRef]

4. Benedict, M.A.; McMahon, E.T. Green Infrastructure: Linking Landscapes and Communities. Island Press: Washington, DC, USA, 2012; ISBN ISBN 978-1-59726-764-9.

5. Dupras, J.; Drouin, C.; André, P.; Gonzalez, A. Towards the Establishment of a Green Infrastructure in the Region of Montreal (Quebec, Canada). Plan. Pract. Res. 2015, 30, 355-375. [CrossRef]

6. European Comission Communication from the Commission to the European Parliament, the Council, the European Economic and Social Committee and the Committee of the Regions. Green Infrastructure (GI)—Enhancing Europe's Natural Capital. Brussels. Available online: https:/ / eur-lex.europa.eu/resource.html?uri=cellar:d41348f2-01d5-4abe-b817-4c73e6f1b2df.0014.0 3/DOC_1\&format=PDF (accessed on 14 August 2020).

7. Pauleit, S.; Ambrose-Oji, B.; Andersson, E.; Anton, B.; Buijs, A.; Haase, D.; Elands, B.; Hansen, R.; Kowarik, I.; Kronenberg, J.; et al. Advancing Urban Green Infrastructure in Europe: Outcomes and Reflections from the GREEN SURGE Project. Urban For. Urban Green. 2018. [CrossRef]

8. Girma, Y.; Terefe, H.; Pauleit, S.; Kindu, M. Urban Green Infrastructure Planning in Ethiopia: The Case of Emerging Towns of Oromia Special Zone Surrounding Finfinne. J. Urban Manag. 2018. [CrossRef]

9. Jones, S.; Somper, C. The Role of Green Infrastructure in Climate Change Adaptation in London. Geogr. J. 2014, 180, 191-196. [CrossRef]

10. Wilker, J.; Rusche, K.; Rymsa-Fitschen, C. Improving Participation in Green Infrastructure Planning. Plan. Pract. Res. 2016, 31, 229-249. [CrossRef]

11. Kabisch, N. Ecosystem Service Implementation and Governance Challenges in Urban Green Space Planning-The Case of Berlin, Germany. Land Use Policy 2015, 42, 557-567. [CrossRef]

12. Bolund, P.; Hunhammar, S. Ecosystem Services in Urban Areas. Ecol. Econ. 1999, 29, 293-301. [CrossRef]

13. Demuzere, M.; Orru, K.; Heidrich, O.; Olazabal, E.; Geneletti, D.; Orru, H.; Bhave, A.G.; Mittal, N.; Feliu, E.; Faehnle, M. Mitigating and Adapting to Climate Change: Multi-Functional and Multi-Scale Assessment of Green Urban Infrastructure. J. Environ. Manag. 2014, 146, 107-115. [CrossRef]

14. Forest Research. Benefits of Green Infrastructure; Report by Forest Research; Forest Research: Farnham, UK, $2010 ;$ p. 42.

15. Tzoulas, K.; Korpela, K.; Venn, S.; Yli-Pelkonen, V.; Kaźmierczak, A.; Niemela, J.; James, P. Promoting Ecosystem and Human Health in Urban Areas Using Green Infrastructure: A Literature Review. Landsc. Urban Plan. 2007, 81, 167-178. [CrossRef]

16. Wang, J.; Banzhaf, E. Towards a Better Understanding of Green Infrastructure: A Critical Review. Ecol. Indic. 2018, 85, 758-772. [CrossRef]

17. Teixeira, C.P.; Fernandes, C.O.; Ahern, J.; Honrado, J.P.; Farinha-Marques, P. Urban Ecological Novelty Assessment: Implications for Urban Green Infrastructure Planning and Management. Sci. Total Environ. 2021, 773, 145121. [CrossRef] [PubMed]

18. Mell, I.; Clement, S. Progressing Green Infrastructure Planning: Understanding Its Scalar, Temporal, Geo-Spatial and Disciplinary Evolution. Impact Assess. Proj. Apprais. 2019. [CrossRef]

19. Mell, I.; Allin, S.; Reimer, M.; Wilker, J. Strategic Green Infrastructure Planning in Germany and the UK: A Transnational Evaluation of the Evolution of Urban Greening Policy and Practice. Int. Plan. Stud. 2017, 22, 333-349. [CrossRef]

20. Rall, E.; Hansen, R.; Pauleit, S. The Added Value of Public Participation GIS (PPGIS)for Urban Green Infrastructure Planning. Urban For. Urban Green. 2019, 40, 264-274. [CrossRef]

21. He, J.; Yi, H.; Liu, J. Urban Green Space Recreational Service Assessment and Management: A Conceptual Model Based on the Service Generation Process. Ecol. Econ. 2016, 124, 59-68. [CrossRef] 
22. Kappel, C.V.; Martone, R.G. Ecosystem-Based Management-The Encyclopedia of Earth. Available online: https:/ / editors.eol. org/eoearth/wiki/Ecosystem-based_management (accessed on 26 May 2021).

23. Shandas, V.; Matsler, A.M.; Caughman, L.; Harris, A. Towards the Implementation of Green Stormwater Infrastructure: Perspectives from Municipal Managers in the Pacific Northwest. J. Environ. Plan. Manag. 2020, 63, 959-980. [CrossRef]

24. Silva, R.; Chávez, V.; Bouma, T.J.; van Tussenbroek, B.I.; Arkema, K.K.; Martínez, M.L.; Oumeraci, H.; Heymans, J.J.; Osorio, A.F.; Mendoza, E.; et al. The Incorporation of Biophysical and Social Components in Coastal Management. Estuaries Coasts 2019, 42, 1695-1708. [CrossRef]

25. Hansen, R.; Rall, E.; Chapman, E.; Rolf, W.; Pauleit, S. GREEN SURGE-Urban Green Infrastructure Planning-A Guide For Practitioners. 2017. Available online: https:/ /ign.ku.dk/english/green-surge/ (accessed on 19 July 2021).

26. Llausàs, A.; Roe, M. Green Infrastructure Planning: Cross-National Analysis between the North East of England (UK) and Catalonia (Spain). Eur. Plan. Stud. 2012, 20, 641-663. [CrossRef]

27. Conway, T.M.; Khan, A.; Esak, N. An Analysis of Green Infrastructure in Municipal Policy: Divergent Meaning and Terminology in the Greater Toronto Area. Land Use Policy 2020, 99, 104864. [CrossRef]

28. Parker, J.; Zingoni de Baro, M.E. Green Infrastructure in the Urban Environment: A Systematic Quantitative Review. Sustainability 2019, 11, 3182. [CrossRef]

29. Mell, I.C. Aligning Fragmented Planning Structures through a Green Infrastructure Approach to Urban Development in the UK and USA. Urban For. Urban Green. 2014, 13, 612-620. [CrossRef]

30. $\mathrm{Hu}, \mathrm{T}$;; Chang, J.; Syrbe, R.-U. Green Infrastructure Planning in Germany and China: A Comparative Approach to Green Space Policy and Planning Structure. Res. Urban. Ser. 2020, 6, 99-126. [CrossRef]

31. Cilliers, E.J. Reflecting on Green Infrastructure and Spatial Planning in Africa: The Complexities, Perceptions, and Way Forward. Sustainability 2019, 11, 455. [CrossRef]

32. Dobbs, C.; Escobedo, F.J.; Zipperer, W.C. A Framework for Developing Urban Forest Ecosystem Services and Goods Indicators. Landsc. Urban Plan. 2011, 99, 196-206. [CrossRef]

33. Setúbal Climate: Average Temperature, Weather by Month, Setúbal Water Temperature—Climate-Data.Org. Available online: https:/ / en.climate-data.org/europe/portugal/setubal/setubal-137/ (accessed on 17 May 2021).

34. Santos, A.; Tavares, A.O.; Emidio, A. Comparative Tsunami Vulnerability Assessment of an Urban Area: An Analysis of Setúbal City, Portugal. Appl. Geogr. 2014, 55, 19-29. [CrossRef]

35. Monteiro, R.; Ferreira, J.C. Green Infrastructure Planning as a Climate Change and Risk Adaptation Tool in Coastal Urban Areas. J. Coast. Res. 2020, 95, 889-893. [CrossRef]

36. Cunha, N.S.; Magalhães, M.R. Methodology for Mapping the National Ecological Network to Mainland Portugal: A Planning Tool towards a Green Infrastructure. Ecol. Indic. 2019, 104, 802-818. [CrossRef]

37. Caparrós Martínez, J.L.; Milán García, J.; Rueda López, N.; de Pablo Valenciano, J. Mapping Green Infrastructure and Socioeconomic Indicators as a Public Management Tool: The Case of the Municipalities of Andalusia (Spain). Environ. Sci. Eur. 2020, 32, 144. [CrossRef] [PubMed]

38. Ma, Q.; Li, Y.; Xu, L. Identification of Green Infrastructure Networks Based on Ecosystem Services in a Rapidly Urbanizing Area. J. Clean. Prod. 2021, 300, 126945. [CrossRef]

39. Lennon, M.; Scott, M.; Collier, M.; Foley, K. Developing Green Infrastructure 'Thinking': Devising and Applying an Interactive Group-Based Methodology for Practitioners. J. Environ. Plan. Manag. 2016, 59, 843-865. [CrossRef]

40. Pyszny, K.; Sojka, M.; Wróżyński, R. LiDAR Based Urban Vegetation Mapping as a Basis of Green Infrastructure Planning. E3s Web Conf. 2020, 171, 02008. [CrossRef]

41. Bai, Y.; Guo, R. The Construction of Green Infrastructure Network in the Perspectives of Ecosystem Services and Ecological Sensitivity: The Case of Harbin, China. Glob. Ecol. Conserv. 2021, 27, e01534. [CrossRef]

42. Santos, A.; Sousa, N.; Kremers, H.; Bucho, J.L. Building Resilient Urban Communities: The Case Study of Setubal Municipality, Portugal. Geosciences 2020, 10, 243. [CrossRef]

43. Zêzere, J.; Neves, M.; Reis, E.; Fonseca, N.; Pereira, S.; Santos, Â.; Lopes, A.; Correira, E. Avaliação e Cartografia de Riscos Naturais, Mistos e Tecnológicos no Concelho de Setúbal Versão 3; Universidade de Lisboa: Lisboa, Portugal, 2020; p. 137.

44. Correia, F.N.; Fordham, M.; Da, M.; Saraiva, G.; Bernardo, F. Flood Hazard Assessment and Management: Interface with the Public. Water Resour. Manag. 1998, 12, 209-227. [CrossRef]

45. Hasala, D.; Supak, S.; Rivers, L. Green Infrastructure Site Selection in the Walnut Creek Wetland Community: A Case Study from Southeast Raleigh, North Carolina. Landsc. Urban Plan. 2020, 196, 103743. [CrossRef]

46. Szulczewska, B.; Giedych, R.; Maksymiuk, G. Can We Face the Challenge: How to Implement a Theoretical Concept of Green Infrastructure into Planning Practice? Warsaw Case Study. Landsc. Res. 2017, 42, 176-194. [CrossRef]

47. Ramyar, R.; Saeedi, S.; Bryant, M.; Davatgar, A.; Mortaz Hedjri, G. Ecosystem Services Mapping for Green Infrastructure Planning-The Case of Tehran. Sci. Total Environ. 2020, 703. [CrossRef] 